\title{
O POEMA E A PRECE NA POESIA MODERNA NACIONAL
}

\section{THE POEM AND THE PRAYER IN THE BRAZILIAN MODERN POETRY}

\author{
Rosana Rodrigues da SILVA ${ }^{12}$
}

\begin{abstract}
RESUMO: Os poemas de inspiração religiosa possuem estruturação semelhante ou idêntica à dos textos bíblicos. A análise desses poemas permite reconhecer formas litúrgicas, em especial a forma salmódica, e formas das narrativas dos patriarcas. $\mathrm{O}$ recurso à fantasia ditatorial $\mathrm{e}$ ao diálogo faz do texto poético um texto simbólico, caracterizando uma poética de semantismo místico e velado. Muitos poetas nacionais criaram movidos por esse tipo de inspiração, dando voz a um sujeito lírico, em um contexto de expressão artística, que realiza preces, convida a reflexões, clama e dialoga com o transcendente.
\end{abstract}

PALAVRAS-CHAVE: Poesia moderna brasileira; Simbolismo; Poesia; Religião; Poema e prece.

ABSTRACT: Poems of a religious inspiration have similar or identical to the biblical texts. The analysis of these poems allows us to recognize liturgical forms, especially the psalmody way, and the forms of patriarchal narratives. The resource to dictatorial fantasy and dialogue makes the poetic text a symbolic one, featuring a poetics of mystical and veiled semantics. Many modern Brazilian poets created moved by this kind of inspiration, giving voice to a lyrical subject in a context of artistic expression, which performs prayers, invites for reflection, calls and talks to the transcendent.

KEYWORDS: Brazilian modern poetry; Symbolism; Poetry; Religion; Poem and prayer.

Senhor Jesus, o século está podre. Onde é que vou buscar poesia?

Jorge de Lima

A atitude idealista dos autores modernos de inspiração religiosa coloca-os em um plano diferenciado de seus contemporâneos. Os poetas pretendem a vidência divina,

\footnotetext{
${ }^{12}$ Departamento de Letras. Universidade do Mato Grosso (UNEMAT) - Sinop - MT - CEP 78555-096 Brasil - rosana.rodrigues@unemat-net.br
} 
uma vez que se julgam artistas privilegiados, conhecedores de mistérios, cuja opção estética se faz pela forma litúrgica de uma poesia que se pretende ritualística.

Entre os autores da vertente metafísico-religiosa, os nomes de Jorge de Lima, Murilo Mendes, Cecília Meireles e Vinícius de Moraes destacam-se como nomes representativos da poesia moderna brasileira e que produziram, cada um a seu modo, variando no grau de tensão criadora, uma obra que perfaz o caminho da tradição romântica e simbolista.

\section{As formas litúrgicas e o poema religioso}

A poética de inspiração religiosa concilia o tema sagrado à forma bíblica ou litúrgica, confirmando que "sentido e forma são idênticos na poesia" (HAMBURGER, 1986, p.179) - uma vez que não se pode distinguir no poema realizado se é a forma que produz sentido ou se é este que comanda a forma. Com isso, a análise dos aspectos formais não prescinde dos temáticos. Ao contrário, possibilita uma exploração mais lúcida da semântica do poema religioso.

A matéria do poeta inspirado pelas imagens de Deus se casa com uma atitude reflexiva, em poemas à semelhança de salmos e orações, ou ainda em poemas em prosa, ao modo das narrativas das parábolas e dos episódios da vida dos patriarcas do Antigo Testamento.

O poema religioso estrutura-se à semelhança de um texto bíblico, como também os textos da Bíblia se assemelham ao texto poético. Os salmos de Davi, os livros de orações e de canções e outros livros bíblicos apresentam a forma de poemas líricos, uma vez que se encontram em primeira pessoa, no enunciado de um "eu" que implora, reza e confessa a sua fé. Refletindo sobre essa relação, Käte Hamburger argumenta que o texto bíblico não pertence ao gênero lírico; pois não é o conteúdo dos salmos que irá determinar o gênero, mas o sujeito de enunciação. No texto litúrgico, o sujeito que enuncia é pragmático, um eu congregacional, "orientado objetivamente assim como o sujeito de enunciação histórico ou teórico" (1986, p. 172). Se incluído em um livro de poesia, ou lido isoladamente, um texto religioso passa a constituir uma expressão artística de um homem devoto.

Assim, um poema lírico pode apresentar a mesma estruturação de um salmo, mas esse último incorpora o sentido doutrinador para o qual foi criado e ao qual se submete como instrumento litúrgico. Conforme consta na bíblia, os salmos são hinos de louvores construídos quase sempre no mesmo plano. Um simples invitatório ou uma 
simples exclamação abre o salmo. Ora o salmista interpela-se a si mesmo, ora apela à comunidade, a alguns de seus membros ou nações, à natureza ou aos liturgos celestes. $\mathrm{O}$ corpo do poema desenvolverá os motivos de louvor, enquanto o fim retoma a introdução, resumindo os motivos e expondo as fórmulas de bênçãos ou augúrios, com possibilidades de variantes ${ }^{13}$.

Segundo Alter e Kermode (1997), os salmos de louvor podem ser celebrações gerais dos atributos majestáticos de Deus, de seu poder criador manifesto na criação visível (p. 267). O poema lírico de Murilo Mendes, extraído de Tempo e eternidade, exemplifica a forma do saltério:

"Salmo n.3"

Eu te proclamo grande, admirável, Não porque fizeste o sol para presidir o dia $\mathrm{E}$ as estrelas para presidirem a noite;

Não porque fizeste a terra e tudo que se contém nela, Frutos do campo, flores, cinemas e locomotivas;

Não porque fizeste o mar e tudo o que se contém nele,

Seus animais, suas plantas, seus submarinos, suas sereias:

Eu te proclamo grande e admirável eternamente

Porque te fazes minúsculo na eucaristia,

Tanto assim que qualquer um, mesmo frágil, te contém.

(MENDES, 1994, p.251-252).

O poema inicia-se com a proclamação de Deus, seguida da exposição dos motivos desse louvor, tal como no saltério bíblico. O eu poético encerra, retomando no oitavo verso, a proclamação: "eu te proclamo grande e admirável eternamente". Completa o louvor com a explicação da grandeza de Deus. Com isso, não deixa de dar caráter sapiente e didático ao poema, tal como se vê nos textos bíblicos. O paralelismo sintático, presente no segundo, quarto e sexto versos ("não porque fizeste"...) completa o semantismo da oração. Deus é proclamado porque fez o sol, a terra e o mar, mas, sobretudo, porque se fez "minúsculo na eucaristia". O paralelismo, característica prevalecente do versículo bíblico (ALTER, KERMODE, 1997, p. 654), auxilia o acréscimo semântico e a ordenação do texto em consonância com a fé religiosa. A repetição intensifica o significado religioso do poema.

A exaltação de Deus se deve às criações oferecidas ao homem, desde as mais simples, como uma flor, à grandiosidade do mar. Deve-se, sobretudo, pela transformação do corpo de Cristo no pão. A operação divina que o poeta proclama é a

\footnotetext{
${ }^{13}$ Cf. Salmos. Introdução. Bíblia, p. 698.
} 
magnitude da eucaristia que permite a todos, mesmo aos frágeis, unir-se a Cristo pela transubstanciação da hóstia.

A criação do mundo torna-se "arquétipo de todo gesto criador humano, seja qual for seu plano de referência" (ELIADE, 1992, p. 44). A criação divina que seduz o poeta leva-o a criar poesia. Sua arte apresenta imagens que funcionam como signos de uma liturgia cósmica.

Jorge de Lima apropria-se de certos episódios bíblicos, recuperando a estrutura e a temática do texto religioso, como faz no poema "A morte dos reis" (de Tempo e eternidade - livro que, como se sabe, Lima e Mendes publicaram juntos em 1935), que recupera o episódio de $A$ escrita na parede ${ }^{14}$ :

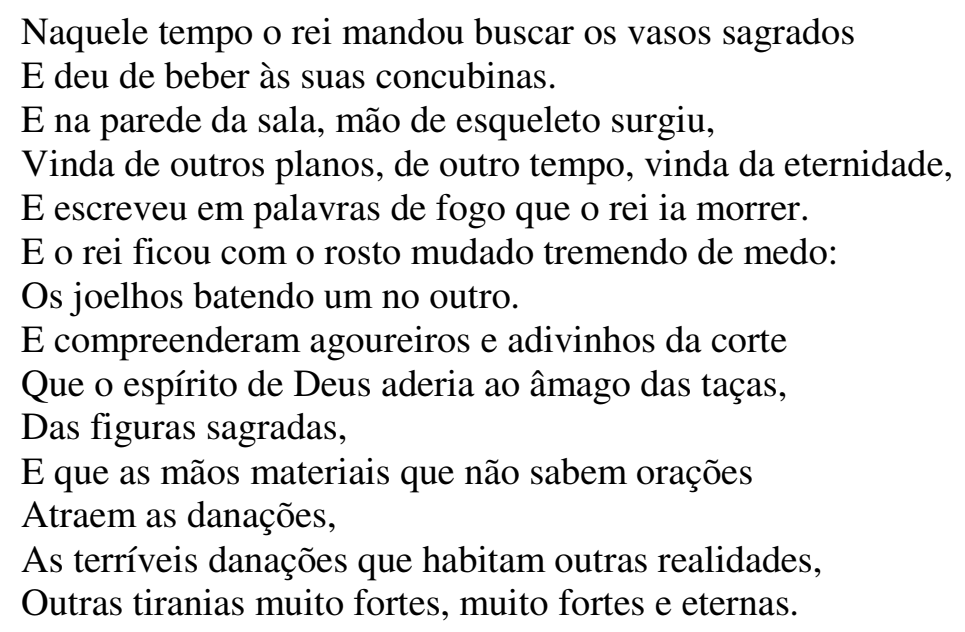

(LIMA, 1997, p.343-344).

Nesta narrativa é relatado o momento em que o profeta Daniel, extraordinário interpretador de enigmas e sonhos, consegue desvendar o mistério de uma escrita. $\mathrm{O}$ rei Baltasar, durante um banquete, mandou trazer os utensílios de ouro e prata, "os vasos sagrados", do templo de Jerusalém, para que todos os presentes neles degustassem vinho e louvassem os deuses do paganismo. Do nada surgiu uma mão de homem que escreveu no gesso da parede palavras indecifráveis. Daniel, tendo sido chamado para decifrá-las, previu nas escritas a morte do rei.

A narrativa do poema, iniciada pela expressão "naquele tempo", transporta o leitor às origens, uma época em que os mistérios estão ainda por descobrir. A linguagem bíblica traz representações simbólicas em que subsistem vestígios de uma antiga mitologia, com seres sobrenaturais e com acontecimentos maravilhosos.

\footnotetext{
${ }^{14}$ A Bíblia. (Daniel, 4:5).
} 
A repetição de elementos, como a conjunção "e" no início dos versos, ("E deu de beber.../ E na parede da sala.../E o rei ficou.../ E compreenderam...”), prolonga o discurso religioso, dando um tom litúrgico ao enunciado, pois o que foi dito, assim se realizou. A parataxe instaura um discurso profético, em que o sujeito enunciador configura-se porta-voz de um mistério que encobre a história do judaísmo cristão.

Os textos bíblicos são identificados, de modo geral, com uma visão histórica dos fatos. Em toda narrativa, como também em boa parte da poesia bíblica, o domínio no qual a invenção literária e a imaginação religiosa estão unidas é a história, pois todas essas narrativas são apresentadas como relatos verdadeiros de coisas que ocorreram no tempo histórico (ALTER, KERMODE, 1997, p. 29). Daí as narrativas bíblicas estarem repletas de dados históricos e localizações geográficas.

Contudo, o gênero narrativo nem sempre trará clareza no significado. O mistério presente nessas narrativas, as chamadas reticências dos escritores hebreus, levou Auerbach (apud ALTER, KERMODE, 1997, p. 36) a falar da narrativa hebraica como um texto "cheio de significado". Os pronunciamentos de Daniel são intencionalmente velados, a fim de evitar que leitores não iniciados desvendassem visões apocalípticas (ALTER, KERMODE, 1997, p. 376). A narrativa velada constitui um recurso apropriado aos poemas religiosos, pois atende à palavra poética que não se submete à condição utilitarista de uma fala prosaica.

A obscuridade do significado recobre de mistério os versos de "Ode da Comunhão dos Santos" (de A túnica inconsútil, 1938; poema dedicado a Alceu Amoroso Lima), de Jorge de Lima, que parafraseia o Evangelho de São João. Vejamos os parágrafos iniciais do poema em prosa:

In principio erat Verbum erat apud Deum, et Deus erat Verbum.

Eu vejo a tua Igreja desde o princípio, Deus Altíssimo.

Amo como cristão e como poeta possuir esta idade remota, e ter presenciado os dias em que Tu pairavas sobre o limo verde das águas ainda mornas pelo fogo dos céus.

A minha memória sobrenatural de poeta e de cristão se recorda do grandes dias do princípio, quando eu existia apenas no Teu Verbo que já derramava sobre as águas primevas, a voz imortal que pronunciaste pela boca dos Teus patriarcas, pela boca de Teus profetas, pela voz do Teu Filho Unigênito. Depois, a Tua voz se calou para renascer na minha boca e nos grandes silêncios de Tua solidão que é mais sonora que as trombetas da terra.

$[\ldots]$

(LIMA, 1997, p.407-408). 
O poema narrativo, uma ode de forma extensa, é um louvor aos Santos da Igreja. O poeta missionário transpõe os séculos e presencia a criação do mundo. Sua fala inicial em latim recupera o mesmo início do Evangelho de São João, buscando recuperar o ato de criação, como no Gênesis - quando Deus cria, nomeando através do Verbo.

O poeta é aquele que teve o privilégio de acompanhar a criação do mundo; possui uma idade remota, evidenciada no verso: "Deus pairava sobre o limo verde das águas". A sua "memória sobrenatural de poeta e de cristão" torna possível recordar os grandes dias do princípio, quando existia apenas no Verbo divino. Sua recordação não é única ou individual, mas uma reminiscência de toda a humanidade:

$[\ldots]$

Eu me lembro de Tuas mãos modelando o meu corpo; e o barro de minha estátua se transformando em carne, ossos e pensamento. Eu me lembro de quando tiraste de mim uma companheira, e de nó dois - o filho para reproduzirmos a Tua Trindade e sermos Tua justa semelhança. Teu exterior me seduz quando vejo Eva ou vejo o meu filho ou vejo o meu amigo, e o glorifico e Te agradeço porque me sinto enxertado e crescendo em Tua própria substância trina e una. $[\ldots]$

(LIMA, 1997, p.408).

Todo o poema simboliza um rito de passagem, em que o sujeito poético busca tornar-se um iniciado capaz de desvendar os desígnios divinos. A saída de Ur a caminho de Damasco é um meio para esse sujeito sentir a hereditariedade de Deus e entrar em comunhão com os homens, com os santos cristãos. Em seu clamor, o poeta convida todos os povos para a reconciliação na grande ceia. Através da bênção em latim, o poeta resgata a bênção originária mais próxima do verbo divino. Purifica-se e salva-se pelo benedictio. Assim, almeja alcançar, por meio dos versos, um encontro com Deus. Seu texto assume um alto teor religioso, na medida em que pretende ser um evangelho. Assim como no início Deus era Verbo e sua vontade se fazia por meio da palavra, é por meio dela que o poeta pretende-se mais próximo de Deus.

O poema encerra-se com a preconização de um fim. Todos compreendiam, nesse fim suposto, o número sete e todos adoraram o Pai, o Filho e o Espírito Santo, com seu amor infinito pelas três igrejas incorporadas à sua Essência, Eternidade e Doxa. O número sete simboliza a conclusão do mundo e a totalidade humana, mas devido à sua própria completude, o sete pode significar também o início de uma mudança. Com isso, simboliza a totalidade em movimento, a chave do Apocalipse (CHEVALIER, GHEERBRANT, 1995, p. 826). Por meio dessa simbologia, o poeta preconiza uma 
renovação positiva; recria o evangelho, transformando seu poema em um texto profético.

A forma narrativa do poema religioso, com Vinícius de Moraes, reveste-se de versos longos com acentos bíblicos. O poema "O único caminho" poderá assemelhar-se às narrativas bíblicas, recompondo um tempo mítico:

Naquele tempo as pombas brincavam com as crianças.

$\mathrm{E}$ os homens morriam na guerra cobertos de sangue.

Naquele tempo as mulheres davam de dia o trabalho da palha e da lã

E davam de noite, ao homem cansado, a volúpia amorosa do corpo.

(MORAES, 1998).

A reiteração ("naquele tempo") atribui à palavra poética a função de uma fala sagrada que remete a um tempo remoto e religioso. $\mathrm{O}$ recurso à reiteração da conjunção "e", tal como nos poemas jorgianos, colabora para o sentido litúrgico. A ideia de um tempo mítico recuperado, tal como é possível reconhecer no Antigo Testamento, traz consigo a imagem de um tempo anterior à profanação da história.

O poema-prece "Senhor, eu não sou digno" recupera a forma do texto bíblico e exprime o sentimento religioso do sujeito que enuncia como se estivesse orando.

Para que cantarei nas montanhas sem eco

As minhas louvações?

A tristeza de não poder atingir o infinito

Embargará de lágrimas a minha voz.

Para que entoarei o salmo harmonioso

Se tenho na alma um de-profundis?

Minha voz jamais será clara como a voz das crianças

Minha voz tem as inflexões dos brados de martírio

Minha voz enrouqueceu no desespero...

Para que cantarei

Se em vez de belos cânticos serenos

A solidão escutará gemidos?

Antes ir. Ir pelas montanhas sem eco

(MORAES, 1998).

O poema estrutura-se como um canto de louvor, mas, contrariamente ao saltério, o sujeito poético não faz as louvações pretendidas. No lugar do louvor, há a interrogação sobre a eficácia de seu canto humano. O "salmo harmonioso" e os "belos cânticos" se tornam "gemidos" na "voz fraca" do homem indigno. O poeta vive o conflito espiritual de saber-se pecador. Sua figura assemelha-se ao poeta amaldiçoado, ao molde dos românticos e simbolistas. 
Reconhecer-se indigno do perdão divino e do alcance das palavras divinas faz do sujeito poético um ser consciente da ineficácia e impotência de sua voz. Sua súplica questiona a eficácia da fala humana dirigida a Deus e a possibilidade de respostas. A voz enrouquecida, marcada pelo desespero, não possui o dom necessário para "atingir o infinito". A consciência dessa incapacidade opera no eu poético a crença no silêncio como meio possível de situá-lo e de torná-lo comunicável com Deus.

A essência do homem é definida por duas dimensões dialógicas: sua relação com o outro e sua relação com Deus (ALTER, KERMODE, 197, p. 59). O poeta religioso costuma questionar-se sobre o seu passado e dialogar com seus ancestrais, mas Deus é o receptor mais evocado nos poemas. O discurso sobre Deus, conforme explica Kuschel, não acontece por via monológica-abstrata, mas pela dialógica-concreta, porque a profundidade do real só se revela sob a forma do encontro (1999, p. 225). O próprio homem já pode ser entendido como um ser dialógico de Deus. A criação do homem à imagem divina propõe um diálogo ancestral entre Criador e criatura.

O diálogo na poesia de Cecília Meireles dar-se-á com a divindade, consigo mesma e com seu outro, representação de seu lado espiritual. A autocompreensão, que representa uma busca muito forte em sua poesia, é a base para o sujeito lírico refletir sobre o sentido de sua vida terrena e sua missão enquanto espírito de luz.

Em vez da forma narrativa do poema em prosa, Cecília Meireles recorre ao ritmo ágil do poema lírico de verso breve. A poeta, em “Auto-retrato" (de Mar absoluto e outros poemas, 1945), alcança um ritmo circular, em que o sujeito lírico enuncia como deve ser e deixar de ser, como unir-se e multiplicar-se, ser um e ser muitos. Enunciado desse modo o poema adquire a unidade e o ritmo de uma oração, na fala de alguém que pretende ver explicadas sua multiplicidade e sua permanência em um universo desconcertado e finito.

\author{
Se me contemplo, \\ tantas me vejo, \\ que não entendo \\ quem sou, no tempo \\ do pensamento. \\ $[\ldots]$ \\ Múltipla, venço \\ este tormento \\ do mundo eterno \\ que em mim carrego:
}




\section{e, una, contemplo \\ o jogo inquieto \\ em que padeço. \\ $[\ldots]$ \\ (Voltas do tempo \\ - sabido e aceito - \\ do seu desterro...).}

(MEIRELES, 1972, p.106-107).

O longo poema, com estrofes breves e versos curtos de quatro sílabas poéticas, juntamente com formas no gerúndio, cria um ritmo que colabora para a visão do desdobramento lírico. As rimas finais e o acento marcado na $2^{\mathrm{a}}$ e na $4^{\mathrm{a}}$ sílabas ocasionam o efeito do retorno na imagem das "voltas do tempo". O uso do desdobramento lírico pode auxiliar o sujeito enunciador na compreensão de si mesmo e do universo. Não é no real presente que a poeta encontrará respostas às suas indagações, mas em uma realidade metafísica.

A estrutura da obra ceciliana comprova seu fundamento religioso nas formas líricas e nas narrativas da vida de santos: Pequeno oratório de Santa Clara (1955), Romance de Santa Cecília (1957), Oratório de Santa Maria Egipcíaca (1986) ${ }^{15}$. Em Cânticos $(1982)^{16}$, a poeta recupera o modelo do Eclesiastes, orientando e alertando para a inutilidade dos esforços do ser humano que pretende fugir de sua condição terrena. Enquanto nos Cânticos dos Cânticos, de Salomão, tem-se um autor preocupado em revelar o papel do amor carnal, descrevendo a união amorosa como modelo de todo amor humano, o Eclesiastes mostra como cada realidade humana comporta seu aspecto negativo e seus limites, a começar pelo contraste entre duração infinita e os instantes efêmeros. O livro bíblico prega que o homem deve viver moderadamente, pois Deus oferece aos homens uma felicidade verdadeira que deve ser desfrutada sem apegos exagerados.

Nos seus Cânticos, Cecília Meireles faz uso da sapiencial bíblica, por meio de admoestações, como no I: "Não queiras ter Pátria./ Não dividas a Terra./ Não dividas o Céu. [...]” (MEIRELES, 2003, p.11). Somente desse modo, pela renúncia ("Cântico XXVI), “[...] tu verás o que vias: / Mas tu verás melhor...” (p.61).

\footnotetext{
${ }^{15}$ Obra de publicação póstuma, escrita alguns anos após a publicação de Pequeno Oratório de Santa Clara e do Romance de Santa Cecília, conforme Alexei Bueno, em Introdução, pela Editora Nova Fronteira, 1986.

${ }^{16} 1982$ é a data da primeira edição.
} 
No Eclesiastes, o mundo é considerado uma ordem baseada em um princípio de justiça distributiva. Conforme a humanidade se volta para o mundo, do mesmo modo dele irá receber. Assim, o mundo é essencialmente retribuidor no sentido do latim retribuare, "pagar, dar, recompensar" (ALTER, KERMODE, 1997, p. 284). Seguindo a mesma concepção, a poeta ordena ao leitor uma existência que negue o domínio da terra, céu e mar, para uma vida desapegada de bens terrenos. Unindo à sabedoria do Eclesiastes a filosofia platônica, seu poema torna-se uma oração que conclui pela inutilidade dos esforços humanos para fugir à sua condição.

O diálogo de Vinícius de Moraes com Deus tornou-se mais dramático em Forma e exegese. O poeta aumenta o desespero de sua obra inicial:

Dize-lhes, Senhor, que és o Deus da Justiça e não da covardia Dize-lhes que o espírito é da luta e não do crime.

Dize-lhes, Senhor, que não é tarde!

(MORAES, 1998).

No saltério bíblico, os hinos dirigidos ao Senhor também podem estar associados a súplicas, em situação de angústia. Assim como nos salmos o fiel que ora não é um ser solitário, pois se reconhece como parte do povo de Deus, o sujeito lírico roga pelas "almas sãs" que "creem na redenção". No saltério, o pedido de socorro se desenvolve, primeiramente, com a invocação do nome divino, seguido do pedido, e para concluir o fiel exprime expectativa e esperança no atendimento de sua prece. No poema, o sujeito lírico clama por salvação. Consciente do mundo do pecado em que vive o homem atual, o sujeito busca o diálogo com Deus e roga-lhe que responda aos seus irmãos, mostrando-lhes o caminho. A insistência é marcada pela repetição do verbo: "Dizelhes”. Muito presente nos textos do Antigo Testamento, a repetição de sons, palavras ou versos inteiros pode conferir ao texto religioso a potência necessária à eficácia da voz no diálogo com Deus.

No poema religioso, o diálogo com o transcendente proporciona ao sujeito lírico a integração em um espaço acolhedor, muitas vezes simbolizado pela terra prometida.

\section{A fantasia ditatorial e o poema religioso}

Ao lado desse diálogo com o transcendente, a própria imagem poética adquire função transcendental, por meio de uma fantasia que se torna autônoma, irredutível a qualquer referente externo. A fantasia, característica da lírica moderna, constitui 
também uma forma recorrente no lirismo religioso. Longe de ser uma nova técnica literária, a fantasia sempre se manifestou em literatura, por meio da imaginação e do senso de mistério, incitando a gama necessária para o processo poético. Os românticos e simbolistas tinham no inconsciente onírico e nos estados de sonho o momento ideal para a criação artística. A fantasia tende, na literatura moderna, a tornar-se um polo criador que deseja ultrapassar as barreiras impostas pelo real. Livre de qualquer interferência que possa reduzi-la à categoria do mundo circundante, a fantasia torna-se ditatorial.

Conforme demonstrou Friedrich (1992), a lírica do século XX é marcada por uma obscuridade proveniente da supressão entre fantasia e realidade. A fantasia deixa de ser medida pela lógica e torna-se absoluta, em um contexto independente que lhe permite medir-se só consigo mesma. Nivelando o real e o irreal, a fantasia se mede pelo que produz, pelas imagens autônomas que ganham força no poema.

A religiosidade nos textos modernos pretende alcançar uma imagem do absoluto. Imagem essa que o recurso à fantasia ditatorial poderá proporcionar. Os poemas, como extensão da obra divina, constituem uma fala absoluta que não pode ser definida pela transcendência vazia. A aniquilação total do "eu", do mundo ou da subjetividade não constitui recurso coerente para o poema religioso.

A fantasia ditatorial constitui uma das origens das transformações e destruições do mundo real no texto literário. $\mathrm{O}$ mundo torna-se fantástico, com imagens que ignoram ou aniquilam a realidade. Nesse universo poético, o espaço é decomposto, permanecendo incoerente; enquanto o tempo assume uma função anormal. Por vezes, elementos distintos no tempo são postos em um único espaço, aumentando sua incoerência.

$\mathrm{O}$ espaço alógico, fruto dessa fantasia, está presente no poema narrativo "A graça” (de Tempo e eternidade), de Murilo Mendes (p.246):

Desaba uma chuva de pedras, uma enxurrada de estátuas de ídolos caindo, manequins descoloridos, figuras vermelhas se desencarnando dos livros que encarnam as ações dos humanos.

E o meu corpo espera sereno o fim deste acontecimento, mas a minha alma se debate porque o tempo rola, rola.

Até que tu, impaciente, rebentas a grade do sacrário; e me estendes os braços: e posso atravessar contigo o mundo em pânico.

E o arco-de-Deus se levanta sobre mim, criação transformada.

No poema, tudo figura como em um sonho. Os espaços se cruzam, as figuras saem dos livros e entram no mundo humano do poeta que, desdobrado de seu corpo, 
integra um outro espaço através dos braços da divindade. Manuel Bandeira já observou que a abstração do espaço na poesia muriliana acaba por "abolir as perspectivas dos planos" que se confundem numa "super-realidade", com a "tangência do invisível pelo visível" (1995, p. 36). O "mundo em pânico" é a denominação melhor desse espaço caótico, onde chovem "pedras", "estátuas", "ídolos”, "manequins". O inverossímil desordena o espaço e o torna incoerente. A graça divina não se harmoniza com a chuva de pedras, da mesma forma como o corpo sereno contrasta com a alma que se debate.

A fantasia é capaz de proporcionar a urgência que faz do poema um despertar do inconsciente rumo à organização do caos. O sentimento religioso e a presença de Deus consentem ao poema a consonância com a ordem desejada, mesmo que seja alógica. Conforme Kuschel, o discurso religioso ocorre nos limites extremos das possibilidades da linguagem, com a certeza de que o inexplicável constitui fundamento de toda reflexão sobre Deus e de que o diálogo só se consuma na dialética entre a fala e o silêncio (1999, p. 125).

Na poesia de Jorge de Lima ("A planície e as flores carnívoras", de Tempo $e$ eternidade), a fantasia impera, dominando a maior parte das imagens, graças à descida às fontes do inconsciente.

Era uma imensa planície sem começo, sem fim.

Nela corriam rios e cavalos, muitos cavalos brancos, rios murmurejando, cavalos nitrindo doidos.

Uma velha tarde de mil séculos sem ocasos berrantes circundava a planície.

Que doçura pacífica abrangia a planície!

Que solidão amiga havia entre os ginetes!

Como venciam os milênios essas bestas gigantes!

Como nascia o silêncio de seus rinchos de fogo!

E pairando no tempo uma voz sussurrava.

Que voz era essa tão presente e tão forte?

Não desejeis saber, a força humana não pode.

Mas no além da planície

Uma noite existia abraçando a floresta, a floresta, Senhor, uma floresta morna onde o teu inimigo semeou carnes brancas de princesas banidas, de mulheres raríssimas fechando as pálpebras para mim.

Quando deixei a floresta, Senhor, na planície só havia grandes flores carnívoras. Os abutres tinham descido sobre os cavalos brancos. A noite tinha caído sobre o suor dos rios.

$$
\text { (LIMA, 1997, p.333). }
$$


O espaço da planície, "sem fim e sem começo", é um lugar sem dimensões. O tempo, "tarde de mil séculos", forma um período que não se destina à vida humana. Portanto, a planície atemporal e infinita constitui um espaço paradisíaco, com sua "doçura pacífica" e com sua "solidão amiga". Contudo, na sequência narrativa a que se presta o poema, as imagens acolhedoras cedem lugar para uma visão espantosa. O verso ["mas no além da planície"] marca o início dessa transformação, lembrando o poeta que no além existia uma noite e uma floresta, a floresta do inimigo de Deus. A partir daí, as imagens serão de trevas, de "flores carnívoras" e de "abutres" sobre os "cavalos brancos". A imagem da noite faz o poeta se lembrar da queda humana e da mortalidade.

A fantasia faz emergir no texto um espaço antagônico ao jardim do Éden. O senso de mistério permanece na imagem do abutre que pressente a morte e desce sobre os cavalos da planície. O inconsciente coletivo da imagem da queda humana está simbolizado na planície. Avaliar esse inconsciente, descobrir suas terríveis verdades, ocasiona o medo e a fuga. $O$ sujeito poético deixa a floresta; pretende não mais presenciar o cenário aterrorizante, noturno e devorador, como a própria mente humana pode ser em momentos de solidão e medo.

As imagens escatológicas, recuperadas pela descida da noite e dos abutres, evidenciam um cenário apocalíptico. O gênero apocalíptico costuma ser representado como se ocorresse em um sonho ou visão, à maneira da poesia onírica (ALTER, KERMODE, 1997, p. 414). É, portanto, explicável a relação entre apocalipse e fantasia. A fantasia ditatorial torna-se recurso para o poeta expressar, obscuramente, tal como no Apocalipse, a visão do fim dos tempos.

Em $O$ visionário, de Murilo Mendes, a visão apocalíptica é dada pela fantasia de uma outra realidade, incompreensível e incoerente, fragmentada no todo, como faz exemplo o poema "Metade pássaro":

\footnotetext{
A mulher do fim do mundo

Dá de comer às roseiras,

Dá de beber às estátuas,

Dá de sonhar aos poetas.

A mulher do fim do mundo Chama a luz com um assobio, Faz a virgem virar pedra, Cura a tempestade Desvia o curso dos sonhos, Escreve cartas ao rio, Me puxa do sono eterno
} 
Para os seus braços que cantam.

(MENDES, 1995, p.223-224).

Tudo é fantasiado pelo sujeito poético, sem deixar de formar uma realidade, aquela onde o próprio irreal se configura. No texto, o poeta nivela a impossibilidade ao mesmo grau de uma coisa possível: as roseiras que comem, as estátuas que bebem, os poetas que sonham. No paralelismo sintático, recupera-se também o semântico. O paralelismo dos verbos ("comer", "beber" e "sonhar") identifica o semantismo dessas ações. O sonho do poeta é tão possível quanto a comida da roseira e a bebida da estátua. Se não há lógica para a rosa e a estátua, não haverá também para o poeta, proibido de sonhar.

A mulher do fim do mundo faz as coisas impossíveis; figura a imagem do fim dos tempos. Enquanto representação inversa de uma mulher geradora, que inicia e não finaliza, a mulher do fim do mundo "puxa" o sujeito poético do "sono eterno". Assim ressuscitadora, ao contrário do sopro divino que traz a luz para as trevas, a mulher "chama a luz com um assobio". Por meio da fantasia, o poema propõe uma inversão dos sentidos do poeta, eternizando momentos, na figura da estátua virgem, e modificando os cursos naturais. A fantasia que nele impera rompe com a ordem da verossimilhança, para mostrar como o irreal pode ter lógica, enquanto revelador das perturbações da mente humana.

Na obra A túnica inconsútil, Jorge de Lima reordena o universo que compõe o texto poético, fantasiando-o em uma dimensão mítica, como nos fragmentos do poema "Os treze dias a caminho do deserto" (dedicado a Adolfo Casais Monteiro):

$[\ldots]$ no sexto dia, a terra se fendeu e milhões de cabeças decepadas se incorporaram ao desfile;

e essas cabeças que tinham sido de grandes alucinados e de grandes precursores conservaram adiante delas as visões nunca vistas e muitas coisas que apenas começavam a nascer;

e depois das cabeças vinha a nação dos videntes, dos tocantes e dos ouvintes

$[\ldots]$

(LIMA, 1997, p.403-405).

As imagens sobrepostas, o raro emprego de vírgulas e as enumerações surrealistas são responsáveis por imagens de fantasia imperiosa, em que o poeta imagina seus dias de peregrino no deserto. 
Conforme consta na Bíblia, o deserto e a terra prometida se fundem. O deserto exemplifica o pleno potencial de uma vida de exílio. Como lugar onde tudo foi perdido, pode revelar também o espaço onde tudo será ganho. O Levítico vê o deserto como lacuna necessária entre diferentes culturas, entre passado e futuro, uma lacuna que deve ser transposta para que o povo possa receber a ordem simbólica redentora da Lei (ALTER, KERMODE, 1997, p. 90). Desse modo, o deserto é o espaço de um rito de iniciação. O iniciado, após ausentar-se de seu espaço original, é recolhido em cenários como o deserto. Segundo Alter e Kermode (1997), no rito de agregação é necessário o momento de exílio.

Na poesia de Vinícius de Moraes, a força mágica e assustadora que paira sobre a mente do pecador é posta pela fantasia reinante. A visão surrealista é evidenciada nas imagens oníricas do poema "A última parábola" (de Forma e exegese):

No céu um dia eu vi - quando? - era na tarde roxa

As nuvens brancas e ligeiras do levante contarem a história estranha e desconhecida

De um cordeiro de luz que pastava no poente distante num grande espaço aberto.

$[\ldots]$

(MORAES, 2011, p.51).

A fantasia ditatorial impede que as imagens visionárias se convertam em fragmentos de um mundo real. A visão permanece fantástica:

[...]

A mulher nua baila para um chefe árabe mas este corta-lhe a cabeça com uma espada

E atira-a sobre o colo de Jesus entre os pequeninos.

$[\ldots]$ (p.51).

A imagem do cordeiro transformado em mulher nua para fugir ao ataque do lobo compõe uma metáfora irredutível, da qual não se pode retirar conclusões lógicas.

A fusão de diferentes níveis da realidade compõe aquilo que a realidade não comporta. As subordinações alógicas em "a mulher nua baila para um chefe árabe mas este corta-lhe a cabeça com uma espada" ilustram a dissonância. A sintaxe alógica e a falta de coerência discursiva tornam o poema obscuro. A tendência narrativa não está 
em acordo com aquilo que é narrado no poema, pois a simplicidade como a mensagem vem posta choca-se com a inextrincabilidade do que está sendo dito.

A falta de lógica nesse poema, proveniente da visão surreal que adota o sujeito poético, é adequada à sua parábola. Enquanto "última parábola”, o texto traz um espaço apocalíptico, que ilustra um fantasmagórico fim do mundo. A fantasia reinante, na obra religiosa de Vinícius de Moraes, ganha mais força a cada poema.

Cecília Meireles apresenta uma visão fantástica, desvencilhada do mundo real e com menor dramaticidade, se comparada a Vinícius de Moraes ou a Murilo Mendes. Conforme Bosi (1989, p.515) já assinalou, Cecília distancia-se do real imediato e "norteia os processos imagéticos para a sombra, o indefinido, quando não para o sentimento da ausência e do nada”. Com ela, a fantasia ganha o rumo do transponível, pois rompe as barreiras entre real e imaginário e põe em questão a ideia formada que se tem do real intuído. Sua religiosidade mostra mundos diversos ou planos diversos de um só mundo. O mundo onírico impregna, portanto, a composição da realidade diversa, como no poema "Irrealidade" (de Mar absoluto):

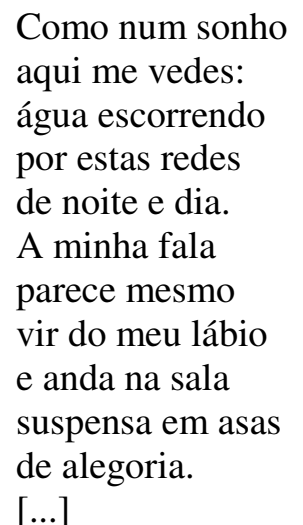

(MEIRELES, 1972, p.109-110).

O sujeito lírico apresenta-se de forma distante, dividido entre realidade e sonho. A fantasia, nesse sentido, desempenha a função de fazer reviver um mundo oculto. Novamente, a fantasia traz para o poema a dissonância entre o conteúdo e a forma. A forma é simples, com um léxico simplificado, num poema com tendência narrativa, mas a mensagem exposta requer atenção dobrada. O sujeito expõe sua irrealidade, formando um contraponto com o mundo real. O simbolismo da água escorrendo faz reviver a imagem do tempo passando para um sujeito que se sente estranho no espaço terreno. Sem compreender-se, nitidamente, não consegue reconhecer a origem de sua fala, percebe-a como "suspensa em asas de alegoria", representando ideias que não são do 
interior de um eu-lírico. Desdobrado, esse sujeito compreende-se longe e ausente e assim permanece, como em uma vigília, a contemplar o teatro da vida. A irrealidade, portanto, está na vivência de um mundo real.

A distinção de mundos é frequente na poesia ceciliana. Contudo, não se trata de uma visão que se finda em abstrações sem respostas, ou em ostracismo. Sua reflexão acerca-se de um mundo estereotipado e sentencioso, do qual a poeta recusa-se a tomar parte.

A fantasia ditatorial auxilia para dar a forma do Absoluto, mesmo que quase impossibilitada. O Absoluto não é visível, mas sentido; não é explicável, mas aceito; não é questionado, mas contemplado. O Absoluto está na descoberta do sujeito poético que, contemplando um mar visível, capta o sentido sagrado da vida.

\section{Conclusão}

A poesia religiosa do século XX orienta-se por esta questão com frequência, podendo mesmo nela se resumir: a busca do sentido religioso acaba deflagrando um conceito de poesia como criação, simulação do ato divino. Assim, restaurando o sentido demiúrgico, a poesia religiosa pretende uma linguagem carregada de um sentido mágico e incomunicável, para dizer, não os conteúdos de uma vida religiosa, mas a vivência de um sentimento religioso.

Nessa experiência está incluído o diálogo com o transcendente. Ao mesmo tempo em que constitui temática bastante recuperada, o diálogo orienta o poema para a multivocidade, possibilitando a expressão de diferentes vozes. O sujeito de enunciação dialoga com seu Deus, com o Outro, ou acaba realizando um desdobramento do sujeito de enunciação, em que se tem ora a visão do sujeito poético, ora de um profeta e ora de uma musa inspiradora.

Os poemas religiosos de Murilo Mendes, Jorge de Lima, Vinícius de Moraes e Cecília Meireles apresentam um sujeito de enunciação, em um contexto de expressão artística, que realiza preces, convites a reflexões, movido pela fé religiosa e inspirado em textos bíblicos, principalmente na forma salmódica.

Irredutíveis à realidade, muitos poemas religiosos pretendem participar do mistério divino, encobrindo-se de um poder encantatório. O mergulho na fantasia no poema religioso está profundamente relacionado ao sentido sagrado que se dá ao poema. A visão cosmogônica e escatológica, bem como a declaração do messianismo, transportam o leitor para um universo hermético. Do mesmo modo, os textos bíblicos 
não apresentam clareza de ideias, mas enunciam um conteúdo obscuro, enigmático, compreensível apenas por um leitor iniciado.

O poema como prece, ainda que não seja de fato uma oração, revela a necessidade do autor religioso de realizar uma arte que o faça transcender os meios prosaicos para ser mais do que a sua forma e substância permitem evidenciar.

\section{REFERÊNCIAS}

ALTER, R.; KERMODE, F. (Org.). Guia literário da Bíblia. São Paulo: UNESP, 1997.

BOSI, A. Cecília Meireles. In: História concisa da literatura brasileira. São Paulo: Cultrix, 1989. p.460-3.

CHEVAliER, J.; GHEERBRANT, A. Dicionário de símbolos. Rio de Janeiro: J. Olympio, 1995.

ELIADE, M. O sagrado e o profano. São Paulo: Martins Fontes, 1992.

FRIEDRICH, H. Estrutura da lírica moderna. São Paulo: Martins Fontes, 1992.

GALACHE, G. (Org.) A Bíblia. São Paulo: Loyola, 1995.

HAMBURGER, K. O gênero lírico. In: A lógica da criação literária. São Paulo: Perspectiva, 1986. p.167-209.

KUSCHEL, K.-J. Os escritores e as escrituras (retratos teológico-literários). São Paulo: Loyola, 1999.

LIMA, J. de. Poesia completa. Rio de Janeiro: Nova Aguilar, 1997.

MEIRELES, C. Poesia completa. Rio de Janeiro: Nova Aguilar, 1994.

Cânticos. 3.ed. São Paulo: Moderna, 2003.

. Flor de poemas. 4.ed. Rio de Janeiro: Nova Fronteira, 1972.

MENDES, M. Poesia completa e prosa. Rio de Janeiro: Nova Aguilar, 1995.

MORAES, V. de. Poesia completa e prosa. Rio de Janeiro: Nova Aguilar, 1998.

Forma e exegese. Ariana, a mulher. São Paulo: Companhia das Letras, 2011.

Artigo recebido em 01/04/2011

Aceito para publicação em 29/06/2011 